prove, it has its bright side. Those students who are to be the catalogers of the future should, because of these uncertainties and disagreements, prove more adapt- able in making changes and adjustments when they undertake the building of actual catalogs in libraries and the solution of future cataloging problems.

By FRANCIS G. WILSON

\title{
The Library Catalog and the Scholar
}

\author{
Mr. Wilson is professor of political \\ science, University of Illinois.
}

THE USERS of the college and research Iibrary hardly know that there is a "crisis" in the art and science of cataloging. In degree each professor and student is aware of the virtues and the vices of the catalog but few have any coherent opinions on what might be called policies of the cataloging department of a library. Yet any scholar should welcome the wide discussion among librarians of the question, for it is only the inert and static professional group which has no questions as to its own folkways. The users of libraries will see a hope for continued improvements in the management of the book resources of the nation in the re-examination of cataloging, even though they may not know just what the improvements are to be.

The nonprofessional approach to the catalog would, perhaps, distinguish first of all between the kinds of users of the library. Undergraduates have a certain type of demand, the graduate students another, and the faculty still others. But distinctions must be made between different kinds of faculty men, since some teachers seldom use the library while others regard it as their garden of research which must be carefully cultivated. If the least sympathy need be expended on the teacher who does no research, we must also recognize that the needs of the students generally follow the pattern of demand originating in the teaching process. The values of the teacher are reflected in the demands the students make upon the library. A library catalog is a single instrument which must serve the needs of the whole academic community.

\section{Wider Meaning of Service}

Professional librarians may become immersed in the details of policy and administration and they may therefore forget the wider meaning of the service they are rendering the university. The library is, for the liberal and humane aspect of education, the organic and functioning center of the campus. If the laboratory courses may neglect the treasures of the mind locked up in books, the humanities cannot. Our universities have grown up in measure around the permanence of the library. We assume that the library will continue always to be where it is and that it will be always available to the seeker for knowedge. Americans who have used libraries in Europe will in many cases have realized the achievements of the American librarian, and this realization comes from 
knowing the relative inaccessibility of materials not governed by the modern catalog. Distinguished exceptions may be remembered in the libraries of the League of Nations and the International Labor Office in Geneva where the handiwork of American library science was visible in the arrangement and cataloging of the books. As with the liturgy of a universal church, the scholar is at home anywhere and any time with a good library catalog.

A catalog is the key to effective teaching and research. It is for people to use, always and openly. But "people" are not experts in cataloging, and here as elsewhere the latent conflict between the expert and the layman can be seen. While we may regard the undergraduate as a layman in the extreme meaning of the word, the practiced scholar is a little less of the layman, though not an expert in the librarian's sense of the word. In the field of government, the civil servant or bureaucrat often feels that his knowledge is unappreciated by the citizen-subjects of the modern state. There is continued conflict between the expert or administrator and the ordinary individual upon whom the impact of government falls. So with the library. The librarian must be conscious of rendering a real service to the public and that there is a debt of appreciation which should be shown in refraining at least from capricious criticism. Possessors of the administrative arcanum do not welcome the clumsy curiosity of the uninitiated. Whatever one may say of professional achievements, those in educational endeavor, including librarians, must stand a constant public inspection and a lay evaluation of their work. Law, medicine, and, once upon a time, theology, were accepted and respected by the ordinary mortal, but not education for which the whole society pays good tax dollars. The modern bureaucrat would like to hush his critics with a frown of disapproval but in a democracy let us hope that this will never be. Those who direct the cataloging of a modern library must remember that the bureaucratic virus will weaken their position; it is a disease resolutely to be resisted.

\section{Institutions of Consultation}

One basic solution, long suggested in the discussion of social policy, is to develop institutions of consultation with the recipients of public service. Good opinion, the best opinion indeed, should be consulted. For the cataloger the best opinion available is that of the active scholar. If there are policies to be determined in cataloging, such people should be regularly and formally consulted. It might be suggested that in each university library there should be a general committee of such people, appointed by the librarian, who will be consulted about the problems of cataloging. Scholars will not be unwilling to accept the wisdom of the professional librarian, but the professional librarian may find there is wisdom to be gathered from the scholar. It is not suggested here that the minute problems of what call number should be assigned to a book should be discussed by such a committee but that the larger issues facing the cataloger and administrator of the library should be discussed. The conventional library committee in a university hardly gets beyond the divisions of the budget, the purchase of particular academic rarities, and the discussion of certain equipment needs. If the contemporary librarian faces a crisis which will not be short, he should seek all of the advice on policy that it is possible for him to get. 


\section{Value of the Scholar's Advice}

Librarians are seldom if ever in ivory towers, though students and scholars may be at times. The specific needs of an individual are what the librarian faces, but those needs must be correlated with the general financial and administrative circumstances of a library. Such a correlation cannot be achieved by intra-professional discussion alone. The generalized interests of library users should be consciously studied by the ablest representatives of the consumer of the library service.

Let us assume that the library must accept its share of the critical time through which all public institutions, not military in character, must pass. The brilliant tradition of American library science is stalwart support for troubled days, and a capacity of libraries to hold their own might be about all that can be expected during the next few years. The possibility, even probability, that less money will find its way into library budgets is clear. Some savings must be made. The cataloger, like others, must reduce the cost of his services. To introduce technical imperfections in the process of cataloging may be necessary, provided other values in librarianship are maintained. In the conflict of library values, the consumer, the scholar, should be able to offer valuable advice.

In the abstract, it would seem that the scholar would prefer savings in every branch of library cost before the actual purchase of books and documents is curtailed. To what extent cutting the cost of cataloging will maintain the stream of new books coming into the library is a question for the library technician to answer. It is obvious that a book must be available else it might just as well not be purchased, but it is clear also that there are degrees of availability and an imperfect catalog might be the lesser evil. In the abstract, therefore, if a choice must be made the scholar would prefer simplification in cataloging if such simplification will enable the library to purchase a larger number of books. Yet any scholar knows that long-run issues are involved. It might be shortsighted to mutilate the symmetry of the catalog in order to acquire a limited number of new titles; there might be even added cost at some later date in order to restore coherence to the catalog. Nevertheless, almost any scholar and teacher will urge that one of the vices of the modern university is excessive administrative and maintenance cost, all the way from the library to the athletic program. What simplifications in cataloging should be accepted should, therefore, be a matter for sustained discussion between the professional librarian and the active scholar.

\section{Scholarly Needs Vary}

Scholarly needs vary greatly, yet it would seem there is in general a discrepancy between the perfection of the bibliographical data on the catalog card and the needs of the scholar. In effect the data used by scholars is in most instances governed by publishing practice, though notable and discouraging variations may be noted in the meticulosity of some doctoral dissertations. What a research man ordinarily takes from the catalog card is the data that will go into a published bibliography; if he needs more there are appropriate means of getting it. Or, indeed, his reference may be and usually is made directly from the volume in hand. It is not suggested that the author-title cards 
in the catalogs should be correlated perfectly with the standards of research publication but a closer correlation is at least a possibility in the simplification of cataloging. The ordinary student or graduate student may take even less data from the catalog card.

Subject analysis, may be, perhaps, to the user, the most crucial of the issues in cataloging. Subject headings involve great expense but they are included in the catalog in order to make it more useful. Now many users of the library may urge that the subjects selected are or have become traditional; that they do not keep up with the emergence of new subjects of inquiry. On the other hand, a perfect catalog might require an enormous amount of reclassification rather than the more simple and less expensive process of cross reference to older and obsolete headings. It can readily be understood that a cataloger does not want to have incomplete or dormant headings but the user might urge that new literature on new subjects might begin where the older and traditional division, let us say of a social science, leaves off. Certainly, the consultation of the workers in a discipline, who may be invited from time to time to serve with a general committee, should be important in the constant evolution of subject headings. It might be urged, to be specific, that few scholars in the field of political science would use the subject heading of "Political Science" in the catalog. Clearly, no subject headings can be perfect, though new subjects might reflect the development of sustained research interests, either throughout the field of scholarship or in particular universities. A consultative committee of scholars might be able to indicate the emergent fields of research which should be recognized in the catalog, especially those which cut across the social sciences.

\section{Subject Headings Should Vary}

Subject headings should vary, it would seem, with the changing interests of particular fields and with the changing predominances of research in particular universities. Thus, a university whose faculty has pioneered and attained recognition in a particular field will have both undergraduates and graduates using the catalog for literature dealing with the subject. Why should not the cataloger follow this interest fully as much as the more or less traditional subjects worked out by the $\mathrm{Li}$ brary of Congress? For example, works on the totalitarian state have, we hope, a limited time interest but in future years even a dormant heading on this subject might be of great value in guiding the graduate student in the preliminary stages of his research.

Owing to the traditional procedures of American scholarship, it is doubtful whether the formal bibliography can be a substitute for the catalog in research. Almost any research project goes far afield; it crosses other disciplines and ignores the accepted classifications of subject matter. By definition, a real research project must do this. A research problem springs in part from the spirit, the intuition, and the reason of the investigator; the formality of a library catalog or a bibliography can never keep up with dynamic and determined scholarship. The bibliography can hardly fit a specific research need, though it may be of value to investigations on lower levels of originality. Bibliographies cannot become substitutes for the catalog with its dispassionate revelation of all the material that a library may have.

On the other hand, there are bodies of 
particularly difficult material, such as government and institutional documents, where most scholars do not know the ramifications or the richness of what is available. Analytical bibliographies and subject analysis of government documents might be of great use to the scholar. In practice the researcher knows only a small segment of the publications of a government and when he moves beyond his hardwon documentary competence he is likely to feel lost. While no library should undertake to do all of the bibliographical labor a scholar needs, while a library can attempt to be too systematic in the organization of materials, it is nevertheless true that the librarian should concentrate on those phases of bibliography which prove in practice most difficult for the scholar. Even librarians must remember that some labor need not be saved and that some delays to the user of a library are administratively justified.

\section{The Reference Librarian}

Rather than subject headings and rather than bibliographies, the scholar must turn to the reference librarian to bridge the gaps that are financially or administratively necessary. It is unfortunate that so many research workers are unfamiliar with the assistance that can be got from the trained reference librarian. Any scholar should be in the habit of going to such a librarian with any or all of his bibliographical difficulties. Faculty members as well as students need constant instruction in the use of the library, especially as the field of interest shifts from familiar to unfamiliar bodies of material. As simplification in cataloging becomes more and more necessary, the reference librarian will become correspondingly more and more valuable to the scholar. For example, in certain unsystematized problems of cataloging, such as films, the reference librarian is invaluable to one engaged in research. This statement implies, however, no defense of such unsolved problems.

Whatever is done with the catalog in the future, certain things must be remembered by the administrator and the cataloger. The present and previous generations of American scholars have grown up and reached their maturity under existing cataloging practice. Long use has taught many researchers the difficulties of the present system and how to avoid them. The college library catalog is a fundamental part of the researcher's outlook on life. He knows the catalog is there and he knows some of the things that are in it; he knows that at any time it can direct him here and there through the riches of a research library, as an elaborate map can direct the traveler or the soldier toward his objective. Fundamental changes in the cataloging system would entail almost revolutionary changes in the habits of the research mind. Indeed, it might generate in some a sense of frustration which would be translated into aggressiveness against the very librarian who is trying to adjust the library to his needs in the light of changing circumstance.

\section{Unity of the Single Catalog}

All true students want the resources of a library expanded and preserved. They want books to be available and to be guarded for the use of the future, as for the present, generation of students and scholars. But the diversity of materials in a library is brought at least to a symbolic unity in the single catalog. Our tradition, our use and wont, expects unity in the cata$\log$ if in nothing else about the library. 
Yet all users of a library know that changes are necessary. If a scholar knows, through consultation, what the problems of the librarian are, he will accept those changes more willingly than if he is left in ignorance of the inner workings of the librarian's mind. The simplification arising in cataloging from cost, all will accept, and any other changes which the common interest of librarians and scholars may dictate.

Any person who knows a library from the standpoint of independent research will know how complex the management of great stores of printed material is and likewise he will appreciate the effectiveness of the staffs of university libraries. Whatever changes must be made, should be made in light of the observed needs of the users of libraries and in the light of the experience of the professional librarian. It must be, in the nature of the case, a slow process but one that is constant. The scholar and the librarian both have a profound common interest in the preservation and expansion of the American library. The elements of professional jealousy and scholarly arrogance must fade in the common consciousness of the larger issues before us in the maintenance of the library, scholarly or otherwise, as a functioning element in our democratic way of life.

\section{In Anticipation of Reconstruction}

$A^{\mathrm{N}}$ MERICAN LIBRARIANS in research institutions, harassed during the last several months with missing issues and volumes of foreign journals, can sympathize with their European and Asiatic colleagues. Those librarians have for the last few years had the multiple problem of delivery failures, extensive reductions in budgets, necessitating almost wholesale journal cancellations, and in many instances destruction of important sets already held by the institutions. The size of this complex problem is impossible to estimate at the present time but we have sufficient evidence already to know that it is of huge proportions. And with no immediately cheerful prospects of change in the international situation we can assume that the problems for both foreign and American institutions will continue to multiply.
Whether we in the United States receive aid in completing our sets of foreign journals or not there is considerable satisfaction to be derived from knowing that work has been accomplished in this country which will aid in the future rehabilitation of foreign institutions. The Rockefeller Foundation, with its constant interest in international scholarship, has given to the American Library Association grants totaling $\$$ I I 0,000 to be used to purchase current issues of important American journals to be shipped to European and Asiatic research institutions at the end of hostilities. The Committee on Aid to $\mathrm{Li}$ braries in War Areas has been responsible for the administration of this program. A brief report on the acquisition of this supply appeared in the April 1942 issue of the A.L.A. Bulletin.

(Continued on page 268) 